\title{
Role of Social Studies for Pre-Service Teachers in Citizenship Education
}

\author{
Seyedali Ahrari ${ }^{1}$, Jamilah Othman ${ }^{1}$, Md. Salleh Hassan ${ }^{1}$, Bahaman Abu Samah ${ }^{1} \&$ Jeffrey Lawrence D’Silva ${ }^{1}$ \\ ${ }^{1}$ Institute for Social Science Studies (IPSAS), Universiti Putra Malaysia, Malaysia \\ Correspondence: Seyedali Ahrari, Institute for Social Science Studies (IPSAS), Universiti Putra Malaysia, \\ Malaysia. Tel: 60-162-831-490. E-mail: seyedaliahrari@gmail.com
}

Received: October 8, 2013 Accepted: November 13, 2013 Online Published: November 18, 2013

doi:10.5539/ies.v6n12p1 URL: http://dx.doi.org/10.5539/ies.v6n12p1

\begin{abstract}
Developing pre-service teachers civically is the oldest need which is known for social studies. Social studies are the most humanistic science between other sciences. It is due to the goal of social studies to focus more on civic issues and its content. Teacher students can gain skill, knowledge, and trait of being a good citizen through courses and curricular activities by attending in social studies classrooms. Based on the importance of schools to cultivate civic values, this paper concentrates on prospect teachers as agents of social change for new generation. The civic function of social studies is based on the unique technique brought by them for teaching in classrooms. It is hoped that it may compel educational policymakers to develop future teachers to transmit civic knowledge and values for a democratic society and better responsible citizenship.
\end{abstract}

Keywords: social studies, school, democracy, citizenship, pre-service teachers, thinking skills

\section{Introduction}

Political educators have long discussed the relationship of democracy and education. They state that an initial purpose of education especially social science is helping democracy, the methods that it can fulfill this mission, and replacing new ideas for students (Usta, Dikyol, \& İnce, 2010). Social studies are described as the combination of social science and humanities to make learners as active citizens (Boyle-Baise \& Goodman, 2009, p. 38) and aid them to advance essential information, abilities, and beliefs to be an active citizen (Çengelci, 2013). Öztürk (2009) described social studies as "a teaching plan which combines information and approaches for teaching active citizens" (p. 4). The truly shared connection between education and democracy is that schools make students strong for finding reason as an important promotion for a democratic society. Social studies teachers have reason to the seriously worried about the absence of political participation but it is remained unconnected to the everyday lives of youth and often scholars often fail to analytically examine the association of social studies teaching for democratic purposes. This is because of as a discipline, social studies education has challenged with the difficulty of "too much to teach" (McGuire, 2007, p. 621) which has frequently caused in disengaged actions of facts and small emphasis on generalizations that is a frightening lack of democratic complexity between advance level of pre-service teachers. Another reason to the current failure of social studies mission is that, social studies educators are not able to make democratic values as the first priority for their students' lives (Kahne, Rodriguez, Smith, \& Thiede, 2000) due to their misconception and underestimate of its ability as key changing factor in students' lives and even as social studies educators are not sure about its mission and transmission of its value (Thornton, 2005). Additional problems for pre-service educators include: the largely negative opinions of social studies; the lasting beliefs; chaos about tenor; lacking of make social studies teachers as agent of social change; excessive number of related social studies content at teacher education faculties; and disability for employing the learned materials in everyday life (Henning \& Yendol-Hoppey, 2004). They should again highlight the main objective of these classes about civic competencies and obligations.

\subsection{The Relevance of Social Studies}

Thinking abilities (i.e. reasoning, critical thinking, etc) are vital conceptual components and very difficult to combine the logical and the mental base of every field. Consequently, the sciences and mathematics are mostly using a scientific thinking skill like problem solving tactic but the social sciences traditionally employ critical way of thinking for their evaluation. However, every discipline requires both types of thinking skills. Before social studies recognized as an interdisciplinary paradigm, it was in the format of civic and history syllabus was 
taught in schools (Brophy, 1990). Truthfully, some instructors see these thinking skills of their students as a treat for themselves and they institutional position. Pre-service teachers need to be socialized into this system to permit orderly living; but at the same time they should be trained to be constructive social critics of the system. It is through such thinking skills such as deep criticism from citizens that the democratic system is developed. Each student teacher must learn to accept any idea of his or her community and institution after synthesize it and admit this criticism right for their future students. On the other hand, assessments of teacher students functioning suggest that civic education has not been overly effective in developing their civic knowledge (Journell, 2013a) because of not teaching the above competence to their students.

\subsection{Role of Pre-Service Teachers}

The teachers are able to engage themselves in the development of their profession with passing on their experience, not only to educators already in the field but also to the prospect teachers (Tuomi, 2005) and they are confronted teacher education issues to accomplish citizenship actively. To fulfill it, student teachers have top position to lead their future students to a responsible citizen level (Logan, 2011). They must cultivate the sense of responsibility to develop suitable plans and ways to assess their future student learning and they can be the source of enthusiasm among them about the subject of civic skill and knowledge for their students. Instructors should teach prospect teachers to interpret for a multidisciplinary field to realize the citizenship aim of social studies. Anderson and Piazza (1996) highlight that in-service and pre-service teachers, who should be the means of change, are outcomes of the system they are attempting to change. Pre-service teacher educators must determine a strong program for connecting civic information and way of teaching in their classes to engage their students in democratic preparation (C. Pryor \& B. Pryor, 2005). They need to authorize their learners to create and practice a combination of thinking abilities by encouraging teaching (Milligan \& Ragland, 2011) with promoting cultural democracy collectively with citizenship education to facilitate student identity as members of their own "cultural communities, the nation-state, and the global world society" (Banks, 2007, p. 124). They have a very special duty to instruct democratic citizenship and its value especially when they act as "teacher democrats" (Kennedy, 1998).

\section{Differences between Social Studies in School and Higher Education (HE)}

School teachers generally are focused more on the individuals and development of their skills than content. These skills can be gained through teaching process namely are listed as reading, listening, and speaking to cognitive skills such as analysis, synthesis, and evaluation of cause and effect to help problem solving abilities. In a school context, educators teach wide facts in addition to presence of traditions and preferred customs in opposite to higher educational ideas, indication of paradigms, deeper understanding of contents and applications, and finally a critical thinking as a way of living. Higher education (HE) academicians point at concentration excessively on books, idealist fats, illogical skills, bright national attitudes and suspect to the learning process of their students (Brophy, 1990). Instead of focusing on society and family in schools, social studies in the university concentrate more on the content. Content of social studies means facts, information, and philosophy of a socio-political issue. Learning process in university is based more on finding causes of problems, tactics for development, and, when suitable, work jointly, and widening understanding. Universities are the place for discussion, evaluation of current issues for enhancing civic related abilities (Isaac, 1992). Indeed, schools may be the only institutions with specific civic spaces with the capacity to achieve almost all students, assist them to become good citizens where students can feel they are more effective for their community (Carnegie Corporation of New York and the Center for Information and Research on Civic Learning and Engagement (CIRCLE)., 2003; W. C. Parker, 2003). In order for this form of democratic citizenship education to establish, conversely, schools should be considered in terms of their "social significance" for "civic life" (Dewey, 1990, p. 14). Citizenship education as a broad goal of public schooling in general, it is specifically the province of social studies education to cultivate the civic skills, knowledge, and dispositions (Urban, 2013).

\subsection{Approaches to Social Studies}

There are three major traditions explaining approaches in teaching social studies as citizenship transmission, discovering analysis action, and reflective approach. Another category of teaching sees social studies as explanation of content, critical study, and evaluation of challenges (Engle \& Ochoa, 1988). The final classification is based on the Martorella (1985), which classified social studies as passing cultural norms tool, social science, reflective investigation, informed critical thinking, and individual development.

\section{Importance of Social Studies in Citizenship}

There are three type of understanding about social studies among teachers. Social studies are important for teachers to employ them in teaching process which are including: control, knowledge, and power in the classes. 
One general point of agreement regarding the role of social studies has been "citizenship education", as Ross (2006) said: "the preparation of students to be good citizens, they must be knowledgeable, skilful, and understand values (p. 20). Other researchers added the fourth attribute to three above which is "involvement" (Root \& Billig, 2008, p. 107) for fostering the greater good of society (Hartoonian, 1991). However, existed mindful inquiries in trying to express what "citizenship" means including, questions concerning whom it refers to and who created it (Cary, 2010), the influence of locationality and positionality (Shinew, 2006), the flexibility of commitments (Parker \& Mitchell, 2008), and its task in curriculum and instruction (Avery, 2007; Parker, 2004). Citizenship is a main core of social studies which their task is to make their youngsters to be ready for a collective action. Case and Clark (1999) expanded on the objectives of social studies education by reflecting four reasons of citizenship education: commencement, upgrading, individual improvement, and academic information. Majority of social studies teachers consider citizenship transmission as their key role and seek to inspire patriotism, cultural heritage, and political values (Barr, Barth, \& Shermis, 1977). The literature identified three traditions originally introduced by Barr, Barth, and Shermis (1978) that have experienced a long period of discourse revolving around three conflicting objectives saw social studies as:

(1) The oldest view defended as an opportunity for encouraging social assimilation of the dominant society.

(2) Social science which encourages applying the scientific procedures and means to observe the world as a social scientist's world.

(3) A method for social transformation through inquiry based critical and reflective thinking of the views held by the dominant culture.

Addressing these arguments regarding social studies teachers' conceptualizations of social studies through the lens of citizenship education, Anderson, Avery, Pederson, Smith, and Sullivan's (1997) well-constructed study recognized four viewpoints that were corresponding to the three Barr, Barth, and Shermis (1978) founded in addition to some other formerly discussed traditions. The four "widely varying" viewpoints and their main characteristics were:

(1) Critical thinking perspective supports students' reflecting critically on the current situations and laws, asking questions about their school and society and the recognition of their membership in a world community rather than unreflective allegiance to the nation.

(2) Legalist perspective stresses students' obedience and respect for the law and focuses on teaching students their rights.

(3) Pluralist perspective distinguishes the importance of exposing students to a variety of ideological perspectives that reflect the multicultural experiences and values of groups comprising those in the neighbouring community, across the nation and globally.

(4) Assimilationism perspective endorses the transmission of what is viewed as the dominant societal values and thus encourages a sense of nationalism, loyalty and civic duty to their nation.

\section{Means of Citizenship by Social Studies}

As stated by Parker (2003), there are three kinds of citizenship. Traditional citizenship education emphasizes the transmission of values, knowledge, and skills about history and government. Progressive citizenship education, while not altogether eschewing this knowledge base, encourages greater student agency, practice, participation, and action. Yet both of these forms of citizenship, which dominate civic education in many countries, "minimize social and cultural heterogeneity" and distance matters of race, gender, class, and ability (Parker, 1996b, pp. 111-113). To accommodate the diverse needs of students in inclusive social studies classes, one would need to move beyond traditional and progressive notions of citizenship education. Advanced democratic citizenship education takes seriously the idea of popular sovereignty and student agency in the classroom; views democracy as an ongoing, common path rather than as an achievement; and nurtures differentiation as vital mechanisms of democracy (Parker, 1996a). Certainly, this advanced platform of democratic citizenship may not be completely possible in social studies classes, but it is a purpose toward which prospect teachers and teacher educators should try (Urban, 2013). In conclusion, social studies can promote democratic citizenship by bringing higher order thinking (i.e. critical thinking, reflective thinking), discussing controversial issues, problem solving, and decision making to their teaching instructions.

\subsection{Higher Order Thinking}

Teachers can provide students with higher order thinking abilities or as "deep knowledge" by teaching the main and detailed concepts of intended course for finding related issues and making quite complicated sympathies to 
develop citizenship (Kahne et al., 2000; Newmann, Secada, \& Wehlage, 1995, p. 88). In this concept, teachers' role highlights more on enlightening students instead of Dewey's (1916) description of democracy must learn during life which stressed on finding reason, distinguishing, and achieving common value to show the differences in society's members' capacity. Those who graduated from educational institutions such as future teachers must have thinking abilities to adapt themselves with this fast changing world. In contrast with lower order thinking, it is as previously learned knowledge to resolve problems by engaging in tasks for students to interpret, evaluate, or manipulate information (Newmann, 1991). Social studies are powerful in intangible frameworks for explaining the types of this kind of thinking with a mixture of deep knowledge about the content, ability to manage it, and view to show it in the everyday life. It links the democracy to education by developing students' higher order reasoning, involving them in deep inquiry, providing with opportunities to experience democracy, fostering them to approve people who are different from themselves, enabling them to update their understanding about current societal issues, causes, and ways to solve them (explanations) (Kahne et al., 2000; King, 1991) Research on higher order thinking mention different types of perspective about content view as a sophisticated understanding just will be happened with employing of information in the content; skills perspective as thinking means better detailed subject matter, and lastly, is positions perspective with the underlying disposition of thoughtfulness.

\subsection{Critical Thinking}

It helps student teachers for a better adjudication (van Nuland, 2013) and can easily connected to educational idea which leaner is able to find information and expand his or her knowledge about own which is in contrast with the perspective that assumes student as a passive receiver of ready information. Critical thinking is assumed as a process of social studies in the classrooms but not as their goal because it is an entirely private act for explaining and defining the input data which needs instruct and doesn't need any special concentration and emphasis by teachers about small details. It will be gained by paying attention to social subjects and inquiry. Teaching applicable methods can cultivate this kind of thinking in students' mind. According to Paul, Binker, \& Weil (1990) it is disciplined, self-directed thinking to show a high level of cognition with understanding, accuracy, exactness competencies. Last but not least, it is the ability which social studies teachers can teach to their students to find the primary reason of communal issues.

\subsection{Reflective Thinking}

Social studies and education are becoming more focused on reflective thinking. This is a process where students assess what they accept to be true. It is a dynamic and cautious consideration of any idea form of knowledge regard to the grounds that maintain it and the potential decisions to which it tends. Reflective thinking allows students to be cautious about the everyday issues and judge them critically. Social studies teachers employ this kind of thinking as a beginning point to address important themes. These themes are as follows: multicultural education, culturally responsive education, student centered learning, social studies as a discipline and specifically citizenship. In general, we can use media (e.g., Internet, social networking, and etc) as motivational factor to reflect things for student thinking. This kind of thinking is the main object of teaching social studies for making students ability to criticize socio-political problems and solve them appropriately. For making thinking skills work in this perspective, it must have multiple choices for students and possible prevention about dangerous media effects. This perspective should concentrate more on activities and not just be knowledgeable (Bruner, 2009). Engaging in reflective learning allows professional development after leaving the problem.

\subsection{Discussing Controversial Issues}

Studies of teachers have revealed that often what they consider to be "discussions" in their classrooms are actually recitations of replies to scripted questions (Wilen, 2004). True civic discussions, or what Parker (2006) and Parker and Hess (2001) termed seminars and deliberations, are based on factual knowledge. The belief that discussing controversial issues helps democracy because in many democracies people view involvement public talk thoughtfully and deliberately with others as their responsibility to their country (Parker, 2003). This act helps young people to emphasize that their involvement in the community with a greater sense of sharing and participation. Some educationalists propose that students enjoy engaging in controversial issue discussions (Hess \& Posselt, 2002) and it can achieve the envisioned goals of promoting tolerance and civic awareness (Beck, 2003; D. E. Hess, 2002). The educational programs consider this method as their responsibility (Ersoy, 2010). Nowadays, many countries use this perspective that discussion can make students with more tolerance. Adding this method in teaching schedule is important because learners can be aware of civic matter as early as they start their education in school. Unfortunately, teachers do not really use this method in their classes (Asimeng-Boahene, 2007; Gayford, 2002; Oulton, Dillon, \& Grace, 2004; Wilson, Hass, Lauglin, \& Sunal, 
2002). Despite strong theoretical support for adding this method in classes (Hess, 2009; Journell, 2011), research continue to show that teachers are hesitant to broach it (Journell, 2013b). Previous studies indicate that the considerable majority of teachers report an emphasis on this method in their teaching hours (Allen, 2003; Crowe \& Wilen, 2003; Kelly \& Brandes, 2001; Parker \& Hess, 2001). It is completely depends on teachers that how he or she can plan these issues and carry out the hidden messages about citizenship to their students (Ersoy, 2010) even it is instructed by education program. Lastly, the outcome of this kind of skill must able students to recognize a variety of approaches to a subject or social problem and its reason and ways to support it from their own view.

\subsection{Problem Solving}

It is defined as a flexible ability and process which is rooted in either environment or within the student and occurs in a real world. Its intention is to suggest ways for solving between personal conflicts which can be agreeable for all sides (D'Zurilla, Nezu, \& Maydeu-Olivares, 2004). It is a main tool to involve students with a social science understanding by giving them ability to reason critically about current problems (e.g., Evans \& Saxe, 1996). Educational theories about learning highlighted the advantages of inclusion this method in curriculum (Scheurman \& Newmann, 1998). There are many type of social problems which are addressing by this method which are impersonal, personal, between people, and society problems (D'Zurilla et al., 2004). It is determined as a process which a student try to solve an above mentioned problems cognitively and also in the real world, makes many possible solutions and chooses the most effective ones for an ability to be an active citizenship attribution for reducing present stressful life (D'Zurilla et al., 2004).

\subsection{Decision Making Social}

Decision making slowly have become the main core for citizenship education. Specifically in teacher education programs, it is about process, perspective and civilization of student teachers (Bennett, 1991). Teachers encourage students to find shared ideas and let them to handle research, to facilitate group dynamics, and to encourage democratic involvement skills (Allen, 2000). In another way, decision making is appropriate when we assume that all of the citizens (in this case student teachers) are not informed and social studies can able them to make correct decisions about social forces which affect they lives.

\section{Conclusion}

Pre-service teachers acquire democratic citizenship skills such as problem solving, social participation, and media literacy through the social studies courses which are more than the sum of the social sciences. Social studies are not only teaches concepts associated with citizenship, but represents a national story that emphasizes main elements like civic equality, justice, and responsibility. Learning about social studies develop pre-service teachers own individual ethics and principles to teach them to the future students to able them make positive decisions for challenging situations. Student teachers can acquire knowledge, skills, and values of the social studies course if they continue learning social studies outside the classroom. Social studies will be helpful for individual and students when they use societal methods of thinking in their instruction.

\section{Implications}

(1) Use methods to involve student teachers collectively to raise their information, ability, and sense of disposition about civic issues for a better democratic society.

(2) Use a mixture of academic materials and the real life issues of student teachers to have a significance civic behaviour as output.

(3) Amplify discussions of higher order thinking to give feedback to the pre-service teachers responders.

(4) Discuss relevant controversial issues and current social problems in classrooms for more effective social sciences instructions.

(5) Pre-service teachers must learn the social studies citizenship intention and apply them in their future classrooms.

\section{References}

Allen, A. M. A. (2003). Teaching controversial issues: Tensions, dilemmas and challenges of teacher candidates trying to negotiate a critical teaching practice. Unpublished dissertation.

Allen, R. F. (2000). Civic Education and the Decision-Making Process. The Social Studies, 91(1), 5-8. http://dx.doi.org/10.1080/00377990009602434

Anderson, C., Avery, F. G., Pederson, P. V., Smith, E. S., \& Sullivan, J. L. (1997). Effort perspectives on 
citizenship education: A q-method study and survey of social studies teachers. American Educational Research Journal, 34(2), 333-564. http://dx.doi.org/10.3102/00028312034002333

Anderson, D. S., \& Piazza, J. A. (1996). Changing beliefs: Teaching and learning mathematics in constructivist perspective classroom. Action in Teacher Education, 18(20), 51-62. http://dx.doi.org/10.1080/01626620.1996.10462833

Asimeng-Boahene, L. (2007). Creating strategies to deal with problems of teaching controversial issues in social studies education in African schools. Intercultural Education, 18, 231-242. http://dx.doi.org/10.1080/14675980701463588

Avery, P. G. (2007). Civic education in the United States: Increased challenges. Citizenship Teaching and Learning, 3(2), 22-39.

Banks, J. A. (2007). Educating citizens in a multicultural society. ERIC.

Barr, R., Barth, J., \& Shermis, S. (1977). Defining the social studies. Arlington, VA: National Council for the Social Studies.

Barr, R., Barth, J., \& Shermis, S. (1978). The Nature of the Social Studies. Palm Springs, Calif: ETC Publications.

Beck, T. A. (2003). "If he murdered someone, he should get a lawyer": Engaging young children in civics deliberation. Theory and Research in Social Education, 31, 326-346. http://dx.doi.org/10.1080/00933104.2003.10473228

Bennett, C. (1991). An Alternative for Career-Change Preservice Teachers. Journal of Teacher Education, 42, 119-119. http://dx.doi.org/10.1177/002248719104200205

Boyle-Baise, L., \& Goodman, J. (2009). The influence of Harold O. Rugg: Conceptual and pedagogical considerations. The Social Studies, 100, 31-40. http://dx.doi.org/10.3200/TSSS.100.1.31-40

Brophy, J. (1990). Teaching Social Studies for Understanding and Higher-Order Applications. The Elementary School Journal, 90(4), 351-417. http://dx.doi.org/10.1086/461623

Bruner, J. S. (2009). The process of education. Harvard University Press.

Cary, L. J. (2010). Within and against citizenship: Bad girls in deviant subject positions. In A. Segall, E. E. Heilman, \& C. H. Cherryholmes (Eds.). New York, NY: Peter Lang Publishing.

Case, P., \& Clark, R. (1999). Four purposes of citizenship education. In R. Case, \& P. Clark (Eds., pp. 17-27). Vancouver: Pacific Educational Press.

Çengelci, T. (2013). Social Studies Teachers' Views on Learning Outside the Classroom. Educational Sciences: Theory \& Practice, 00(0), 14-19.

Crowe, A. R., \& Wilen, W. (2003). Teaching prospective social studies teacher to use issues-based discussion in their secondary social studies classrooms. The International Social Studies Forum, 3, 303-305.

D’Zurilla, T. J., Nezu, A. M., \& Maydeu-Olivares, A. (2004). Social Problem Solving: Theory and Assessment.

Dewey, J. (1916). Democracy and education. New York: Free Press.

Dewey, J. (1990). The school and society; The child and the curriculum. Chicago: The University of Chicago Press.

Engle, S., \& Ochoa, A. (1988). Education for democratic itizenship: Decision making in the social studies. New York: Teachers College Press.

Ersoy, A. F. (2010). Social studies teacher candidates' views on the controversial issues incorporated into their courses in Turkey. Teaching and Teacher Education, 26, 323-334. http://dx.doi.org/10.1016/j.tate.2009.09.015

Evans, R. W., \& Saxe, D. W. (1996). Handbook on teaching social issues. Washington, DC: National Council for the Social Studies.

Gayford, C. (2002). Controversial environmental issues: a case study for the professional development of science teachers. International Journal of science education, 24, 1191-1200. http://dx.doi.org/10.1080/09500690210134866

Hartoonian, M. (1991). Good education is bad politics: Practices and principles of school reform. Social Education, 55(1), 22-23. 
Henning, M. B., \& Yendol-Hoppey, D. (2004). Context in methods course learning: Lessons for partnership work. Teaching Education, 15(4), 401-416. http://dx.doi.org/10.1080/1047621042000304529

Hess, D., \& Posselt, J. (2002). How high school students experience and learn from the discussion of controversial public issues. Journal of Curriculum and Supervision, 17, 283-314.

Hess, D. E. (2002). Discussing Controversial Public Issues in Secondary Social Studies Classrooms: Learning from Skilled Teachers. Theory \& Research in Social Education, 30(1), 10-41. http://dx.doi.org/10.1080/00933104.2002.10473177

Hess, D. (2009). Principles that promote discussion of controversial issues in the curriculum. Engaging young people in civic life, 59-77.

Isaac, K. (1992). Civics for Democracy: A Journey for Teachers and Students. ERIC.

Journell, W. (2011). Teachers' controversial issue decisions related to race, gender, and religion during the 2008 Presidential election. Theory and Research in Social Education, 39, 348-392. http://dx.doi.org/10.1080/00933104.2011.10473459

Journell, W. (2013a). Learning from each other: what social studies can learn from the controversy surrounding the teaching of evolution in science? Curriculum Journal. http://dx.doi.org/10.1080/09585176.2013.801780

Journell, W. (2013b). What Preservice Social Studies Teachers (Don't) Know About Politics and Current Events-And Why It Matters. Theory \& Research in Social Education, 41(3), 316-351. http://dx.doi.org/10.1080/00933104.2013.812050

Kahne, J., Rodriguez, M., Smith, B. A., \& Thiede, K. (2000). Developing citizens for democracy? Assessing opportunities to learn in Chicago's social studies classrooms. Theory \& Research in Social Education, 28(3), 311-338. http://dx.doi.org/10.1080/00933104.2000.10505911

Kelly, D. M., \& Brandes, G. M. (2001). Shifting out of "Natural" beginning teachers struggles with teaching for social justice. Canadian Journal of Education, 26, 437-454. http://dx.doi.org/10.2307/1602176

Kennedy, K. (1998). Preparing teachers for the new civics education. Asia-Pacific Journal of Teacher Education and Development, 1(2), 33-40.

King, M. B. (1991). Leadership efforts that facilitate thoughtfulness in social studies. Theory and Research in Social Education, 29(4), 367-380. http://dx.doi.org/10.1080/00933104.1991.10505647

Logan, H. H. (2011). Perceptions of Citizenship in Preservice Elementary Social Studies Education. Journal of peace education and social justice, 5(2), 150-178.

Martorella, P. (1985). Elementary social studies: Developing reflective, competent, and concerned citizens. Boston: Little: Brown \& Co.

McGuire, M. E. (2007). What happened to social studies? The disappearing curriculum. Phi Delta Kappan, 88(8), 620-624.

Milligan, E., \& Ragland, R. G. (2011). Educate, Equip, Engage, Empower: A Framework for Preparing Preservice Teachers in Civic Education. Action in Teacher Education, 33(1), 94-107. http://dx.doi.org/10.1080/01626620.2011.559446

Newmann, F. M. (1991). Classroom thoughtfulness and students' higher order thinking: Common indictors and diverse social studies courses. Theory and Research in Social Education, 19(4), 410-433. http://dx.doi.org/10.1080/00933104.1991.10505649

Newmann, F. M., Secada, W. G., \& Wehlage, G. G. (1995). A guide to authentic instruction and assessment: Vision, standards and scoring. Madison, Wisconsin: Wisconsin Center for Education Research.

Oulton, C., Dillon, J., \& Grace, M. M. (2004). Reconceptualising the teaching of controversial issues. International Journal of science education, 26, 411-423. http://dx.doi.org/10.1080/0950069032000072746

Öztürk, C. (2009). Sosyal bilgiler: Toplumsal yaşama disiplinlerarası bir bakış. In C. Öztürk (Ed., pp. 1-31). Ankara: Pegem A Yayıncilik.

Parker, W. C. (1996a). "Advanced” ideas about democracy: Toward a pluralist conception of citizen education. Teachers College Record, 98(1), 104-125.

Parker, W. C. (1996b). Curriculum for democracy. In R. Soder (Ed., pp. 182-210). San Francisco: Jossey-Bass Publishers. 
Parker, W. C. (2003). Teaching democracy: Unity and diversity in public life. New York, NY: Teachers College Press.

Parker, W. C. (2004). Diversity, globalization, and democratic education. In J. Banks (Ed., pp. 433-460). San Francisco: Jossey-Bass.

Parker, W. C. (2006). Public discourses in schools: Purposes, problems, and possibilities. Educational Researcher, 35(8), 11-18. http://dx.doi.org/10.3102/0013189X035008011

Parker, W. C., \& Hess, D. E. (2001). Teaching with and for discussion. Teaching and Teacher Education, 17 , 273-289. http://dx.doi.org/10.1016/S0742-051X(00)00057-3

Parker, W., \& Mitchell, K. (2008). I pledge allegiance to... Flexible citizenship and shifting scales of belonging. The Teachers College Record, 110(4), 775-804.

Paul, R., Binker, A. J. A., \& Weil, D. (1990). Critical thinking handbook: K-3. Rohnert Park, CA: Foundation for Critical Thinking.

Pryor, C. R., \& Pryor, B. W. (2005). Preservice Teachers' Attitudes and Beliefs about Democratic Classroom Practice: Influences on Intentions for Pedagogical Integration. Current Issues in Education, 8. Retrieved from http://cie.asu.edu/volume8/number6/index.html

Root, S., \& Billig, S. H. (2008). Service-learning as a promising approach to high school civic engagement. In J. L. Pace (Ed., pp. 107-127). Albany, NY: State University of New York Press.

Ross, E. W. (2006). The social studies curriculum: Purposes, problems, and possibilities (6th ed.). New York: SUNY.

Scheurman, G., \& Newmann, F. M. (1998). Authentic intellectual work in social studies: putting performance before pedagogy. Social Education, 62(1), 21-35.

Shinew, D. (2006). Citizenship and belonging: Constructing "a sense of place and a place that makes sense". Social studies-The next generation: Re-searching in the postmodern. New York, NY: Peter Lang.

Thornton, S. J. (2005). History and social studies: A question of philosophy. International Journal of Social Education, 20(1), 1-8.

Tuomi, M. T. (2005). Agents of social change in education. Community Development Journal, 40(2), 205-211. http://dx.doi.org/10.1093/cdj/bsi029

Urban, D. J. (2013). Toward a Framework of Inclusive Social Studies: Obstacles and Opportunities in a Preservice Teacher Education Program. COLUMBIA UNIVERSITY.

Usta, S., Dikyol, D. C., \& Ince, E. (2010). The alternative evaluation tools choosen by social and science teacher $\begin{array}{llll}\text { candidates. Procedia-Social and Behavioral Sciences, 2(2), 3457-3462. } & \text { S }\end{array}$ http://dx.doi.org/10.1016/j.sbspro.2010.03.534

Van Nuland, S. (2013). Civil society approaches to teaching anti-corruption. Global Corruption Report: Education, 9, 395.

Wilen, W. W. (2004). Refuting misconceptions about classroom discussion. The Social Studies, 95, 33-39. http://dx.doi.org/10.3200/TSSS.95.1.33-39

Wilson, E. K., Hass, M. E., Lauglin, M. A., \& Sunal, C. S. (2002). Teacher's perspectives on incorporating current controversial issues into the social studies curriculum. The International Social Studies Forum, 2, $31-45$.

\section{Copyrights}

Copyright for this article is retained by the author(s), with first publication rights granted to the journal.

This is an open-access article distributed under the terms and conditions of the Creative Commons Attribution license (http://creativecommons.org/licenses/by/3.0/). 